\title{
The structuralist tradition in economics: methodological and macroeconomics aspects*
}

\author{
FABRÍCIO MISSIO \\ FREDERICO G. JAYME JR. \\ JOSÉ LUÍS OREIRO**
}

\begin{abstract}
RESUMO: Este artigo analisa a tradição estruturalista em economia, com ênfase no papel que as estruturas desempenham no crescimento econômico dos países em desenvolvimento. Uma vez que o assunto em questão é, evidentemente, muito grande para cobrir em um único artigo, a ênfase é exercida sobre os elementos macroeconômicos de tal tradição, ao mesmo tempo em que explora seus aspectos metodológicos. Começa por analisar alguns aspectos gerais do estruturalismo em economia (a sua evolução e origens) associados com o pensamento da CEPAL, neste caso enfocando a dinâmica da relação centro-periferia. Depois disso, o estruturalismo macroeconômico derivado das obras de Taylor $(1983,1991)$ é apresentado, seguido de uma apresentação do neo-estruturalismo. Centrada sobre o conceito de competitividade sistêmica, essa abordagem define uma estratégia para se alcançar o elevado caminho da globalização, entendido aqui como um processo inevitável, apesar de seu envolvimento estar dependente das políticas adotadas. As conclusões mostram as verdadeiras contribuições desta tradição para a teoria econômica.

PALAVRAS-CHAVE: estruturas; restrições e desenvolvimento econômico.
\end{abstract}

ABSTRACT: This paper examines the structuralist tradition in economics, emphasizing the role that structures play in the economic growth of developing countries. Since the subject at hand is evidently too large to cover in a single article, an emphasis has been brought to bear upon the macroeconomic elements of such a tradition, while also exploring its methodological aspects. It begins by analysing some general aspects of structuralism in economics (its evolution and origins) associated with ECLAC thought, in this instance focusing on the dynamics of the center-periphery relationship. Thereafter, the macroeconomic structuralism

\footnotetext{
* The author Frederico G. Jayme Jr would like to thank both CNPq and FAPEMIG for the financing.

** Assistant Professor at Universidade Estadual do Mato Grosso do Sul (UEMS). E-mail: fabriciomissio@ gmail.com; Professor at CEDEPLAR, Universidade Federal de Minas Gerais. E-mail: gonzaga@cedeplar. ufmg.br; Associate Professor at Instituto de Economia da Universidade Federal do Rio de Janeiro, Researcher at CNPq. E-mail: jose.oreiro@ie.ufrj.br. Submetido: 20/Maio/2013; Aprovado: 7/Julho/2014.
} 
derived from the works of Taylor $(1983,1991)$ is presented, followed by a presentation of neo-structuralism. Centred on the concept of systemic competitiveness, this approach defines a strategy to achieve the high road of globalization, understood here as an inevitable process in spite of its engagement being dependent on the policies adopted. The conclusions show the genuine contributions of this tradition to economic theory.

KEYWORDS: structures; constraints and economic development.

JEL Classification: B22; F43; O12.

\section{INTRODUCTION}

This paper reassesses the main insights of structuralist economic theory, focusing on the fact that economic development depends on a series of distinct structures which, mainly for developing countries, impose constraints to growth. In effect, development occurs with changes in the productive structure of the economy and is favoured when such changes take place towards the 'modern' sectors (industrialized and technology-intensive).

The concept of economic structure refers to the composition of productive activities associated with some influences, such as: the specialization pattern in international trade; the technological capacities of the economy, including the educational level of the labour force; the property structure of the production factors; the nature and development basis of institutions; the level of development and restrictions under which certain markets operate (the lack of certain segments of the financial market or the existence of a large unemployment rate, for instance); among others (Ocampo, Rada \& Taylor, 2009).

The contribution of this paper lays in synthetizing the aforementioned tradition, with emphasis on the structuralist method. This allows to contribute for the way of how certain categories (i.e.,, structures) are important for the economic development of periphery countries, as well as for the determination of how these were first developed and later incorporated into what has been defined as structuralist macroeconomics. Indeed, this paper shows the evolution of this approach and the way in which it transformed itself, in order to explain the growth process of developing countries under center-periphery relationship. Clearly, structuralist thought is much more complex than how it is portrayed and revisited in this work, given its diversity of subjects and associated unfoldings. Therefore, this paper focus on the methodological aspects of such tradition as well as on the main elements composing structuralist macroeconomics. Furthermore, its analytical focus lies in the economic structuralism associated with the thought of the Economic Commission for Latin America and the Caribbean (ECLAC, also known for its Latin American acronym CEPAL), not having as an objective the making of a detailed analysis of the 'original' structuralism - although the validity of this otherwise potential objective is duly recognized.

It is noteworthy that this paper strives to follow a chronological order, i.e.,, it presents the developments in structuralist macroeconomics throughout the 1970s and 1980s as an unfolding of the Latin American structuralist approach. It is pos- 
sible that some authors will disagree with this interpretation, in spite of the fact there are enough elements to allow for the establishment of such association ${ }^{1}$. Moreover, it should be observed that ECLAC theory, focused in the structural problems of developing economies has a long-term concern. This implies that the macroeconomic aspects are harder to study specifically or to identify at first, even if these elements become clearer in further stages.

In order to fulfil its aims, this paper is structured in three separate sections, in addition to this introduction and a final remarks section at the end. The first of these, handles the definition of the structuralist tradition, its origins and foundations. The third section presents structuralist macroeconomics, while fourth section discusses neo-structuralism. Finally, we present concluding remarks.

\section{GENERAL METHODOLOGICAL ASPECTS OF THE STRUCTURALIST ECONOMIC TRADITION}

The term 'structuralism' has been used with multiple meanings in different scientific and cultural contexts. Blankenburg, Palma and Tregenna (2008) define structuralism as an essentially theoretical approach which challenges the methods of both empiricism and positivism, with plenty of its insights present in several disciplines throughout the social sciences and humanities. The guiding principle of this approach lies in the idea that each system should be studied as an organized set of inter-related elements and not separated into individual elements to be studied atomistically (organicity of the economic system). In other words, the relations that constitute the structure are more important than their individual elements.

In this context, structuralism distances itself from methodological individualism. According to the latter, the analysis of human action may be carried out from the perspective of individual agents. As such, it states that all social phenomena are better explained by the properties of the individuals comprised within the phenomena. Or even, in other words, that every explanation that involves sociological concepts on a macro level should, at first, be reduced to explanations on a micro level of the individuals and their properties. On the other hand, structuralism largely aligns with methodological holism, to which: (a) totality, as such, can be considered more than simply its parts, or even, more than the sum of its parts (i.e.,, the whole surpasses the sum of the parts); and (b) totality is historically, logically, cognitively and normatively more important (i.e.,, hierarchically superior) than the individuals it contains. Furthermore, it should be taken into consideration that, in its more elaborated versions, structuralism admits the individual behaviour as a product of social relations. This means that structural analysis emphasizes internal relations (i.e.,, interdependency), thus incorporating systemic properties that cannot

\footnotetext{
${ }^{1}$ The objective here is not to defend a thesis in which structuralist macroeconomics would be the natural unfolding of ECLAC theory and thought. The goal is to show that there are plenty of connections between these approaches, and that some of the main characteristics defining the structuralist tradition can be found in both approaches to a greater or lesser extent.
} 
be reduced to their constitutive parts. They are properties of the whole, which the parts do not have on their own, and that emerge from the 'organizational relations' among them. According to Jackson (2003, pp. 727-728):

Structural theory can sometimes turn into holism and give the whole precedence over the parts, yet the original aim of structural ideas - as against holistic ones - was to ensure that the whole could always be transformed, or else the whole-part relationship would be redundant. A structural method, if handled properly, should never congeal into structural wholes that overshadow their component parts.

Street and James (1982) admit that economic structuralism represents a holistic approach that comprises two basic concepts: one related to the economic system and the other to human nature. The first identifies the economic system as a nonequilibrium and evolutionary process instead of an equilibrating mechanism for stable economic relations centred in market activities ${ }^{2}$, while the second conceives human behaviour as characterized by customary patterns resulting from cultural conditioning. It is thus distinct from the conventional (or orthodox) economic point of view, which conceives human behaviour as essentially dedicated to utilitarian motivation and to monetary calculus in a static market system. On the other hand, Di Filippo (2009) understands that structuralism involves four characteristics: a systemic reading of society, a global view, a historic-structural perspective, and the multidimensionality of approaches.

According to structuralist perspective, orthodox economic theory, in order to accredit itself as a positive science of market laws, needs to be abstracted from the specificities of productive structures, institutions, and the other sociological factors integrating the concrete reality of national economic systems. In the words of Taylor (1983, p. 3), "non economic, or even non maximized, forces affecting actions are ruled out of discussion". The abstraction of these characteristics means, in the context of some macroeconomic problems, not only the propensity to confuse the fundamental causes and the sanctioning factors of these problems, but also their main weakness as guidelines to economic policy.

Therefore, the critical posture of the structuralist approach towards orthodox economic thought is underlined. Such a posture defends an alternative form of economic investigation, such as in the Latin American structuralist comprehension of development and underdevelopment, which understands these phenomena as mutually constructive processes within an economically integrated world. In other words, it emphasizes the understanding of the world economy as a unified system with the economic dynamics of its constituting parts, centre and periphery, which

\footnotetext{
${ }^{2}$ Contrary to neoclassical economics, with its concern in characterizing states of equilibrium, this construct aims at conceiving the processes leading to qualitative change in the economic structure without giving up on treating them as orderly and systemic processes. "These changes constitute neither a circular process nor pendulum movements about a center” (Schumpeter, 1982, p. 44).
} 
should be defined in terms of their relations. This analysis is different from those carried out by orthodox economics, which considers relatively independent units.

\section{Origins of Structuralism}

In economic terms, structuralism is generally associated with ECLAC, whose works gave origin to this school of thought in the late 1950s. According to Arndt (1985), the term originally appeared as a reference to an explanation of the inflationary process in Latin America. Nevertheless, it is agreed that structuralist thought in its initial form was created by the economist Raúl Prebisch. In his 1949 manifesto, Prebisch introduced the notion of an international structure divided between an industrial hegemonic centre and an agrarian dependent periphery, both of which determine the existence of an original and unequal development process. According to Bielschowsky (1998), this approach has four analytical components: (i) an historical approach, based on the binary centre-periphery opposition; (ii) an international insertion analysis of Latin America; (iii) a study of the domestic determinants of growth and technological progress; and (iv) an evaluation of arguments favouring or against State intervention.

This emphasis on 'structures' becomes clear, after the works of Prebisch and Furtado, whether such structures are economic, political or social in nature. According to Sunkel (1970), "given the structure of the system, the way in which it works is determined, which in turn originates the results the system produces" (p. 526, free translation from Portuguese). As such, structuralist scholars become conceptually known and recognized by their diagnosis in which 'structural deficiencies', 'bottlenecks' or 'inner dysfunctions' are the factors responsible for the developmental divergences in Latin America. These 'dysfunctions' have two fundamental sources: (i) those of foreign origin, such as the adverse conditions of trade and the limited capacity to import; and (ii) those of domestic origin, such as accelerated population growth, premature urbanization and the expansion of service sectors, as well as the underdevelopment of agricultural production, the reduced dimensions of the domestic markets and the presence of inefficient tributary systems (Street, 1967, p. 55).

The identification of such factors in conjunction with the centre-periphery construct (and the other theses associated with it) has allowed for the development of formal theories with strict connection to economic policy recommendations, which led Seers (1962, pp. 192-193) to state that:

The Latin American school of 'structuralists' [...] must be the first indigenous school of economics in an underdeveloped area. Since economic growth is becoming increasingly fashionable as a subject, and since the weakness in commodity markets, the population boom, and rising economic ambitions appear chronic, the school could acquire in the 1960s an international interest comparable to that of Keynesian economics during the slump-ridden decade of the 1930s.

At this point, it is necessary to highlight two essential aspects. First, one should underline the methodological aspects of Latin American structuralism. In this case, 
two different interpretations can be identified: on the one hand, according to authors such as Gibson (2003) and Jamenson (1986), it would be possible to identify a considerably large part of the origins of economic structuralism, especially that which surfaced in the 1940s and 1950s, as a product or extension of preceding works in other, pre-existing fields of knowledge such as in Levi-Strauss (anthropology), Godelier (sociology), Piaget (psychology), Foucault (philosophy), among others. In this context, Love (2005) states that Latin American structuralism is 'one' among a 'family' of structuralisms (p. 101). Also, that some of the central elements of ECLAC thought could be found in preceding works, such as in the French 'structuralist' school (Blankenburg, Palma \& Tregenna, 2008) or in the German historic economics school (Love, 2005), in the Marxist school (Sunkel, 1989; Lustig, 1988) or in the Keynesian, post-Keynesian and neoclassical traditions (Love, 1996; Lustig, 1988).

On the other hand, the most recognized and widespread interpretation (with which the authors of this paper identify), which is derived especially from the work of Celso Furtado, goes in the opposite direction in the sense of characterizing a 'new structuralist school'. Firstly, because, in Furtado's own words, Latin American structuralism has little to do with its French homonym:

What can be understood by 'structuralist' thought in economics has no direct relation with the French structuralist school, whose general orientation has been to privilege the synchrony axis in social analysis and to establish a 'syntax' of disparities in social organizations. Economic structuralism (a school of thought originated in the first half of the 1950s among Latin American economists) had as its main objective to put in evidence the importance of the 'non-economic parameters' of macroeconomic models. Since the behaviour of economic variables depends largely on these parameters and the nature of the latter can significantly modify itself in phases of social change or when the analytical time horizon is broadened, these parameters must be the object of thorough study. This observation is particularly pertinent in respect to socially and technologically heterogeneous economic systems, such as is the case of underdeveloped economies (Furtado, 2000, p. 95, free translation from Portuguese).

Since non-economic factors integrate the structural matrix of the model with which the economist works ${ }^{3}$, those who gave special emphasis to the study of such parameters were dubbed 'structuralists', or even, according to Fonseca (2009), "not

\footnotetext{
${ }^{3}$ According to Furtado (2000), economists seek to explain unknown phenomena through other phenomena that they do know. In this context, they treat them as quantifiable variables and create models (i.e.,, simplifications of reality) aiming to determine the numerical values of a (endogenous) variable vector from the known values of another (exogenous) variable vector. The way in which the second vector determines the first, i.e.,, the precise set of relations between variables, constitutes the model's structural matrix. If parameter values are specified, the relations between variables take on precise characteristics, thus defining a structure. As such, there is a corresponding, undetermined number of structures for each model.
} 
only does ECLAC structuralism take as its own the ambition to embrace noneconomic variables in its models and theories, but also makes it its exact reason for being, its brand or differential in comparison to other economic schools, as far as methodology is concerned" (p. 876, free translation from Portuguese).

Also, according to Bielschowsky (1998), in other social science disciplines such as linguistics and anthropology, from which 'structuralism' originate, the term typically corresponded to a synchronic or non-historical methodological instrument. On the other hand, in the economic analysis of structuralism, the focus is essentially oriented to the search for diachronic, historical and comparative relations in which special attention is dedicated to the behaviour of social agents and to the trajectory of institutions.

Secondly, Latin America structuralism was a phenomenon clearly belonging to economics. That means it pays tribute not to Lévi-Strauss, but mainly to Max Weber and François Perroux (Fonseca, 2009, p. 871). Furtado directly refers to Perroux in his writings by mentioning that the term 'structure' resembles the French author's classic definition: "Proportions et relations qui caractérisent um ensemble économique localisé dans le temps et dans l'espace ${ }^{4}$ (Pour um approfondissement de la notion de strucure, 1939)" (Furtado, 2000, p. 94). Indeed, although it does not fully abandon this theoretical notion, it gains a different meaning upon incorporation into the structuralist speech by its conceptual recomposition and by the introduction of historical matters and regional specificities into the analysis (Mallorquín, 1999), not to mention the introduction of social matters ${ }^{5}$.

Beyond that, Furtado (2000) makes explicit what would be the genealogic elements of 'structuralism': on the one side is Marxism, from which he states he extracted the idea of 'structures'. In other words, the structuralist analysis gives emphasis to 'social structures', which in turn describe the 'behaviour of economic variables'. Therefore, in order to apply an economic analysis, it is necessary to follow (throughout time) the modifications of the structural matrixes (which accompany the social division of labour) in economic models.

On the other side, he states that economic models are constituted almost in the same way Weber crafts his 'ideal types':

From the point of view of their conception, the models with which the economist works present great similarity with the 'ideal types' introduced by Max Weber. In one case or another, these are representations (which the economist seeks to formalize) of simple or complex elements

\footnotetext{
4 "Proportions and relations that characterize an economic ensemble located in space and time (For a Deepening of the Notion of Structure, 1939)" (Free translation from French).

${ }^{5}$ The statement that structuralism incorporates social and political factors is controversial, since one of its most emphatic criticisms consists in pointing out as a deficiency the fact that ECLAC structuralism neglects variables of political and social nature, such as in Cardoso and Faletto (1970) and Oliveira (2003), among others. Nevertheless, according to Fonseca (2009), upon analyzing Furtado's work in Teoria e Politica do Desenvolvimento Econômico ('Theory and Politics of Economic Development', 1967) one cannot make such statement since, in the aforementioned work, economic and non-economic variables are conjugated.
} 
of social reality, in which all aspects of the represented elements are defined with accuracy, i.e.,, possessing precise logical significance. Thus, the 'market' with which the economist works in price theory is a set of elements abstracted from reality with the virtue of being intelligible in all its aspects. Albeit at this level of abstraction the market model may represent no real situation, even then its value as an analytical instrument is undeniable (Furtado, 2000, p. 94, free translation from Portuguese).

In the exposition of the construction of these macroeconomic models, important characteristics become evident. One of these refers to the link with historical reality, since the "effort to capture economic reality in the scope of a system is due to the work of long-time empiricists dedicated to drawing a map, as complete as possible, of the multiple social processes open to quantitative expression" (Furtado, 2000, p. 96, free translation from Portuguese, highlight added). In other words, historical and statistical studies are indispensable instruments for avoiding hurried theoretical generalizations lacking empirical substantiation.

The other characteristic, which recalls the Schumpeterian concept of ' vision', refers to the proposition according to which every construct has, beforehand, a global idea of economic reality ${ }^{6}$. And since this global idea refers to an historical reality, the macroeconomic model must equally refer to this same historical reality. This means that structural changes and economic phenomena can have different meanings in different periods, so that any analysis is historically contingent ${ }^{7}$.

In summary, the explanatory role of macroeconomic models in the structuralist approach projects itself onto two levels: the first, in which abstract formulations predominate, requires the construction of simplified models or schemes of existing economic systems, based on the stable relations between quantifiable and relevant variables. The second, the historical level, covers the critical study, in confrontation with a given reality, of the basic categories defined in the abstract analysis. It is not enough to construct an abstract model and craft an explanation of its inner workings. Equally important is the verification of the explanatory efficacy of such a model in confrontation with a historical reality. Therefore, the fundamental methodological problem is to define up to what point it is possible to eliminate from an abstract model the simplifying suppositions, incompatible with the historical reality, without invalidating its explanatory efficacy (Furtado, 2000).

The second essential aspect to be highlighted refers to the delimitation of this

\footnotetext{
${ }^{6}$ The subject's historicity can be understood from the Schumpeterian concept of 'vision' or 'world conception' - it represents the pre-analytical cognitive act which supplies the raw material for the analytical effort - which is in turn influenced by social factors, social processes and ideologies into which the investigator is inserted. Moreover, in a concrete effort of scientific elaboration, this 'vision' not only participates in the process but also precedes and pursues it.

${ }^{7}$ ECLAC analysis has used, as its analytical method, the didactics of the contrast between the way in which growth, technical progress and international trade have been processed into the underdeveloped and developed structures. As such, this instrument was not used to describe an ideal process of transformation, but rather to identify the structural hindrances of peripheral economies which prevented their radical transformation (Bielschowsky, 1998, 2000).
} 
thought. This illustrates the fact that there is no consensus within economic literature as to the concept of what would constitute the structuralist approach, or even who the main authors would be. According to Chenery (1975), many times this approach is identified by an initial set of structural hypotheses formed in the 1950s by authors such as Paul Rosenstein-Rodan, Ragnar Nurke, W. Arthur Lewis, Raúl Prebisch, Hans Singer and Gunnar Myrdal, having as its general view a critical position about the thesis of 'free market' efficiency and as its main arguments the presence of imbalances and the inflexibility in the response of prices to incentives. This view is shared by Arndt (1985) and defined by Love (1996) as a more general structuralism, identified as a 'market failure doctrine', which can be understood as an attempt to distinguish itself from both the neoclassical tradition and from neoMarxism. According to Chenery (1975, p. 313):

The structuralist concept of development as characterized by rigidities that limit economic adjustments requires an analytical framework in which external policy is more closely linked to domestic resource allocation than does the neoclassical view, which minimizes these restrictions.

On the other hand, many of the aforementioned authors are identified as 'developmentalist' (Bielschowsky, 2009) or 'development pioneers' (Sanchez-Ancochea, 2007). As demonstrated below, many theoretical insights are common to both authors, even if there are fundamental differences. This shows how the Latin American structuralism constitutes itself into a genuine approach, despite having received an important intellectual stimulus from other thinkers, not necessarily 'structuralists'. According to Seers (1962, pp. 193-194):

Visitors to ECLAC in recent years who have had some influence in the same direction though one would not necessarily call them 'structuralists', have included Thomas Balogh, Hollis Chenery, Nicholas Kaldor, Julio Olivera, Nancy Ruggles, Richard Ruggles, and Jan Tinbergen. I am very well aware that these lists of names could easily be twice or three times as long $[\ldots]$.

Adopting the classification proposed by Sanchez-Ancochea (2007), two structuralist approaches are identified which, despite having connections between them, are fundamentally different: the Anglo-Saxon approach and the Latin American approach, derived from ECLAC ${ }^{8}$. Anglo-Saxon structuralism is identified in theories based on the following key concepts: complementarity and poverty trap (RosensteinRodan, 1943; Nurke, 1953), linkages (Hirschman, 1958), and dualism (Lewis, 1954). This approach concentrates its interest on giving realistic explanations to the causes of underdevelopment. As such, focusing on the determinants of long-

\footnotetext{
${ }^{8}$ This classification is adopted purely for didactical purposes, considering the better characterization it allows. Nevertheless, the outline between them, when even possible to distinguish, is fine at best; Celso Furtado himself, for instance, makes no reference to it when he (briefly) synthesizes the evolution of this, though (1980, chapter 3, pp. 29-40).
} 
term expansion, it seeks to shed light upon the complex and dynamic character of structural change, showing that development involves transformations in demand structures and production capable of driving the country (or region) towards higher productivity trajectories.

The Latin American theory shares many theoretical concepts with the previous approach, including the perception of a tendency to concentrate resources, the insistence on the necessity for structural change in the periphery, and the rejection of comparative advantages theory. Notwithstanding, these two approaches are substantially different. In conclusive terms, the major divergences lie on the perception, on the side of Latin American structuralism, that countries do not follow a universal trajectory towards development, that relations between developed and developing countries are not always mutually beneficial, and that the historical particularities of different periods are important.

Furthermore, in methodological terms, ECLAC's approach is also broader and deeper. It employs the structural-historical method to identify the basic relations between countries in the world economy and, thus, to explain the observable characteristics of peripheral countries as well as to analyse the dynamics of productive and occupational structures typical of those economies. Following the interpretation of Rodriguez (2009), it must be observed that certain basic tendencies in the development of peripheral economies find their explanation in the way in which the productive apparatus keeps transforming itself, or even in the sectorial composition of production. Thus, the analysis is structural, given the necessity to put the characteristics of the economic structures of certain realities in the foreground. Simultaneously, the necessity to consider the conformation or transformation of such structures implies that the method has to be simultaneously historical, since changes in the economic structures are produced through time and, therefore, are only definable and perceptible 'historically'.

Next, the main foundations of this line of thought are presented. The objective is to systematize a referential theoretical framework capable of showing, with a great level of specificity, the core of this line of thought. This shall allow, later on, for the understanding of how some of these questions are incorporated by structuralist macroeconomics and/or by the neo-structuralist approach. As such, the centre-periphery dynamics are brought forth, emphasizing 'foreign'-level restrictions (such as the tendency of international trade to perpetuate an unequal development process) as well as some 'domestic' restrictions, associated with distributive conflict, technological progress, and the execution of production, which constrain the development process in peripheral countries.

\section{Foundations of Latin American Structuralism}

The foundations of Latin American structuralism are originally related to the 'centre-periphery' basic relationship, understood as being historically constituted by the way in which technical progress propagates itself in the world economy. More specifically, it is understood that a hegemonic industrial centre and a dependent agricultural periphery constitute the international relations system. In contrast to the theory of international trade, based on comparative advantages (Heckscher- 
Ohlin-Samuelson), implicitly or explicitly admits the existence of an original and unequal development process.

The central matter is the understanding that technical progress propagates in an unequal way. It is admitted that in the central countries such progress, or the indirect methods of production it generates, propagates to the whole of the productive apparatus in a relatively brief lapse. That happens because in these countries the scarcity of labour and the presence of unions allow increases in real wages through economic growth, which stimulates the continuous emergence of technological innovations intended to substitute labour for capital. As such, the increases of wages drives innovation and deepening of capital intensity, initially in certain branches but later spilling over to all the other branches and sectors of economic activity. Thus, when capital intensity increases - and, with it, labour productivity and wages productivity is also incremented, permitting remuneration to conserve levels compatible with the continuity of accumulation. Furthermore, the mobility of productive resources tends to equalize the incomes in several activity branches (Rodriguez, 2009).

In contrast, the economic growth in the periphery starts from a relative initial backwardness and, after a period called 'outward development', the new techniques are only implemented in primary goods export sectors and in a few economic activities directly related to exports, which start to coexist with the backward sectors. At this phase, the productive structure of the periphery acquires two fundamental traits. On the one hand, its specialized and unilaterally developed character can be highlighted, since a substantial part of the productive resources is destined to successive applications of the primary goods export sector, while the parallel evergrowing and ever-diversifying demand for goods and services is satisfied mostly by imports. The specialization in primary-exports products has direct implications for the new development pattern that emerges when industry spontaneously becomes the major source of economic dynamism, since the industry needs to become more complex (Rodriguez, 2009). On the other hand, this structure is heterogeneous or partially backward, in the sense that sectors in which productivity reaches high levels - especially the exports sectors - and activities in which productivity is significantly low, coexist. In sum, the productive structure of the periphery is specialized and heterogeneous, while that of the centre is diversified (composed by an ample spectrum of economic activities) and homogeneous (insofar as labour productivity reaches relatively similar levels in all activities).

These characteristics end up determining, in peripheral economies, the development of poorly diversified and poorly integrated structures which coexist in a dynamic primary-exports sector. This, in turn, is incapable of disseminating the technical progress to the rest of the economy, of productively employing the aggregate of labour, and of permitting a sustained growth in real wages.

In addition, the rhythm of incorporating technical progress and the increase in productivity are significantly larger in industrial economies (i.e.,, those from the centre), which alone would lead to a secular income differentiation. Such differentiation is amplified by the tendency toward worsening the terms of trade; that is, the tendency of the price of primary goods exports to present an unfavourable evolution in comparison to that of manufactured goods produced by industrialized countries. This implicates a transfer of productivity gains from the peripheral pri- 
mary-exporter to the central countries (i.e.,, industrialized). This leads to the existence of asymmetries in the development of capitalism, which perpetuates and amplifies the peripheral condition of developing economies by the process of unequal trade in the international market.

From the point of view of these characteristics, Latin American structuralism defends a necessity to industrialize peripheral economies: from an 'outward development', based on the expansion of exports, to an 'inward development', based on the enhancement of industrial production. This change is essential because, even if industrialization is the natural course to be followed by peripheral economies, it occurs under conditions of specialization and heterogeneity. This may, however, result in an incapacity to properly compensate the lack of complementarity among productive sectors and thus to overcome its primary-exporting condition. Development planning with the presence of the State is, therefore, necessary.

\section{STRUCTURALIST MACROECONOMICS}

In specialized economic literature, structuralist ideas have been a source of inspiration for studies with macroeconomic models. In reality, what has been called structuralist macroeconomics is a variety of macroeconomic models in which the simpler class of these models is constituted by versions of 'two sectors', while the other, more complex class is constituted by multi-sectorial models. Regarding a series of studies conducted by other authors, there is consensus to appoint Lance Taylor as the scholar responsible for developing and formalizing structuralist macroeconomics. In this approach, one highlights the importance of institutions and the functional distribution of income among productive sectors and social groups ${ }^{9}$.

According to Jamenson (1986), the major methodological element of this approach is the application of mathematical tools to 'third world' economic affairs, as indicated by Taylor $(1979$, p. 2): "Economists long ago learned that mathematical formulations of their problems help clear away logical and metaphysical cobwebs. There is no reason not to apply these tools to models for poor as well as rich countries". In the aforementioned work, the author develops a series of formal models from characteristics (or 'stylized facts') that represent important aspects of underdevelopment. Thus, the fundamental trait of this approach is outlined, that is, the use of a mathematical instrument to characterize 'stylized facts' typical of underdevelopment.

The development of this language becomes important in and to structuralism, since it allows connection with other economic approaches as well as amplification of the degree of specificity of its theories. This permits its expression in formal language that is consonant with the style in which arguments are presented, especially in Anglo-American economic thought. Furthermore, it enhances or differentiates the understanding of structures and mechanisms in the international system. In relation to the latter, Dutt (1994) observes that the use of mathematical instruments allows

\footnotetext{
${ }^{9}$ The contrast with mainstream economics is also evident, which, by centering its approach on maximization, frequently shields its followers from historical and institutional facts.
} 
the definition of particular conditions under which certain results are acquired. For instance, in contrast to the verbal analysis according to which the relations between 'central' and 'peripheral' countries, the outcome is unequal development, the development of mathematical models embracing 'North-South' trade shows that, although that outcome is possible, it is not by any means inevitable.

The development of this formal analysis has evolved not only in its mathematical instruments but also in the characterization of the specificities present in underdevelopment ${ }^{10}$. In one of his pioneering works, Taylor (1979) defines the following 'stylized facts' as typical of this condition:

a) Sectorial differences: these differences can be incorporated into the distinction between tradable and domestic sectors, wherein both (highly) depend on imported intermediary goods; or yet, between the industrial and agricultural sectors, both because of technology and because of different patterns of demand. In this case, the agricultural sector is often not capital dependent and generates great quantities of employment, whereas the demand for its goods can be price-inelastic or income-inelastic. The industrial sector may have prices formed by mark up, established by oligopolistic firms which follow completely different rules.

b) Distributive conflict: changes in real income of the different economic groups take on fundamental importance. In particular, the equilibrium between investment and savings often occurs through 'forced savings' induced by inflation.

c) For many developing countries, currency is the only domestic financial asset worth keeping in substantial quantities. There is no bond market. This blurs the distinction between fiscal policy and monetary policy. In addition, the availability of credit becomes a restriction in economic decisions.

d) The absence and the (poor) quality of statistical data cause the economy to be better represented by accounting identities, stylized facts and intuition.

Later, in Taylor (1983), some of these matters are treated in depth and new stylized facts are incorporated. According to the author, structuralist models incorporate techniques and behavioural relations that emphasize how the distribution of wealth and the levels of product vary in order to satisfy short-term macroeconomic balance equations. Long-term development is dependent on the reactions of 'winners' and 'losers' of these initial adjustments (i.e.,, the distributive conflict).

Finally, in Taylor (1991), the author reiterates his analyses of underdevelopment problems. In the initial chapter, he discusses the structuralist methodology, arguing that economics is, or should be, a historical science in which events unfold within chronological — rather than logical — time, and, therefore, are irreversibly affected by changes and contingencies that occur only once. This means that eco-

\footnotetext{
${ }^{10}$ Dutt and Jameson (1992) observe that current structuralists begin with 'stylized facts' embedded in a coherent system of general accounting national identities and/or in structuralist models of computable balance which use social accounting matrixes, which provides an ample perspective of the system.
} 
nomic analysis cannot lean on the idealized form of reproducible experiments to delineate its content, because "irreducible history is built into all its data points" (Taylor, 1991, p. 1). One can observe, in this case, a strong influence of the historical perspective present in Latin American structuralist thought.

This perspective has strong implications for economic theory, since, for the author, realistic macroeconomics must be based on 'stylized facts', or "empirical generalizations drawn hierarchically at the macro, sectorial, and micro levels about the economy at hand" (Taylor, 1991, p. 5). It is also observable that not every historically based hypothesis is easy to express in mathematical language. It is suggested, then, that theory should take the form of parables or stories intended to explain the past: some formalized, others not. In this case, the aim is to formally integrate elements of the structuralist theory of development with arguments of some mainstream authors, by the notion that these elements are connected to facts through the following structures:

a) The existence of authors with economic 'power': institutions such as the State and/or corporations, interest groups such as proprietors, rentiers or even the traditional peasantry and unorganized labour class - these are not price takers. They can influence the variation of prices and the quantity offered in certain markets. The 'power' centres differ from one economy to another and change with local institutions and history.

b) Macroeconomic causality is influenced by macroeconomic details. However, it generally flows from investment, exports and demand for income, imports and product. Changes in the distribution of income and wealth play a crucial role in the macro adjustment of historical processes, such as in capital accumulation and in technical progress. There is no reason to believe that a macroeconomic balance will involve full employment of labour or installed capacity.

c) The supply of currency is frequently endogenous or 'passive', adjusting itself to activity levels and inflation rates. Nonetheless, this general view does not deny the possibility that the Central Bank may deliberately reduce the growth of the supply of currency (i.e.,, an austerity program).

d) Inflation may decline with monetary tightening. However, structuralists defend that, in many sectors, production decreases in response to reduction in demand. It is also admitted that the origins of inflation are in the unresolved distributive conflict and in the propagation mechanisms available, such as the indexation of contracts.

e) The forms of financial intermediation exercise a strong influence over the macroeconomic system. In developing economies, financial fragility can rapidly lead to a collapse of the system.

f) Given the process of industrialization adopted, intermediary imports and capital goods are required to support local production and capital formation, respectively. In this case, the necessity for imports can be an active restriction. 
g) Development is not a balanced or harmonious process. Technical progress is linked to new investments by independent business activity. The private formation of capital is probably crowded in by public investment through complementarities, as well as it is crowded out by the rise in the interest rate by the banks. For some sectors, the production techniques with economies of scale or decreasing costs become rentable in small economies when income distribution alters demand in its direction; alternatively, several sectors can expand simultaneously.

Ultimately, the analysis of these works shows that structuralist macroeconomics has some fundamental characteristics: (i) emphasis on the economic importance of the set of persons and institutions, in which the theoretical analytical constructs seek to adapt themselves to the available data on the distribution of income and wealth. In this case, each set of economic actors is related to a functional category of distribution of income or production sector, in which it is considered they have different behaviours and partial control over the system; (ii) models are not constructed in real terms, generally being constructed by explicitly including prices and income flows in nominal or monetary terms; (iii) prices are under a variety of control levels by different groups in the economy; (iv) models with more than one sector incorporate consumer response to changes in relative prices (thus incorporating some aspects of traditional theory in what regards the degree of economic rationality and substitution mediated by prices); and (v) the behaviour of models depends crucially on the description of their casual connections with the macroeconomic system, with its 'closure' being chosen and justified based on an empirical and institutional analysis of the economy in question.

Beyond these characteristics, one can observe that structuralist models are constructed in order to allow for direct thinking, in formal terms, about the problems in developing countries. Nevertheless, it is worth noting that the organizing principle of this approach - understood here as the manners by which these explanations are structured in a specific approach — is probably the hardest to identify given its relative 'novelty' (Dutt, 1994).

\section{REVISITING STRUCTURALIST TRADITION: NEO-STRUCTURALISM}

The influence of structuralist thought diminished throughout the 1970s. Simultaneously, the strategy of export promotion and import substitution seen in the 'Asian miracle', as well as the emergence of a new consensus in regard to the necessity to promote the processes of liberalization and stabilization guided by the principles of the 'Washington Consensus', gained strength. In contrast to this decline, neoliberalism emerged and just as rapidly reached and dominated the political and academic circles. This rapid ascension of the neoliberal approach can be largely explained by its deductive coherence, its methodological unity and, obviously, the hegemonic role played by the United States in academic circles.

Amidst the neoliberal ascension and the decline of influence of Latin American thought, economic structuralism survived (nearly exclusively) with the development of 
the aforementioned structuralist macroeconomics. Nevertheless, the negligence by neoliberalism of social and political factors in the implementation of its policies and the resulting frustration in terms of results achieved by them also led to a series of questionings that fomented the emergence of new approaches. On the side of ECLAC, these questionings led to the intellectual convergence around the neo-structuralist synthesis.

The first neo-structuralist ideas were incorporated by ECLAC in the 'expansionist adjustment' structuralist programs (i.e.,, heterodox plans throughout the 1980s), which opposed the neoconservative orthodox programs and had as their objective to adjust and stabilize the economy in order to minimize (regressive and) recessive redistributive effects. What characterize this initial phase are the predominantly short-termed analyses without consensus as to the development strategy to be followed in the long term. According to Lustig $(1988$, p. 48) "en contraste claro con el estructuralismo, se podría decir que el neoestructuralismo pecatalvez - del defecto opuesto: hay mucho énfasis en el análisis de corto plazo y relativamente poco en el de largo plazo" ${ }^{11}$.

Nevertheless, this period was important because it involved a process of selfreflection, learning and reformulation which led to the intellectual convergence in the late 1980s around the neo-structuralist synthesis, in which many of the contributions of the preceding structuralism were revisited and enriched by new members (F. Fajnzylber, French-Davis, N. Lustig, J. Ros, L. Taylor, A. Dutt, among others). The inaugural milestone of this synthesis is associated with the publication of a document called "Productive Transformation with Equity" (ECLAC, 1990). This document defends the idea that Latin America should seek a greater interface with the external market and a new form of state action that fomented a competition style based in productivity gains. ECLAC's diagnosis suggested that Latin American economies remained with a series of 'bottlenecks', largely associated with macroeconomic imbalance, capital plant obsolescence, and technological backwardness.

Starting from this understanding, neo-structuralist thought proposes the adoption of a new economic model based on a 'systemic competitiveness' driven by inter-capitalist competition and managed by the State, in a context of macroeconomic stability, commercial openness and financial deregulation. This new model shares several elements with the preceding structuralist thought, mainly when it admits that the condition of underdevelopment in Latin America cannot be explained by exogenous distortions induced by economic policy but by historical and endogenously structural factors ${ }^{12}$ (e.g.,, unequal distribution of income and wealth,

\footnotetext{
11 "In clear contrast with structuralism, it could be said that neo-structuralism mistakes — perhaps — by the opposite flaw: there is too much emphasis on short-term analysis and relatively little emphasis on long-term ones" (free translation from Spanish).

12 According to Rosales (1988), tangible proof can be found in three characteristics present in Latin American economies at the late 1980s: (a) international specialization in products with little potential dynamics; (b) the prevalence of an uncoordinated, vulnerable and highly heterogeneous pattern which tends to concentrate technical progress and is incapable of productively absorbing growth or the labor force; (c) the persistence of a concentrated and exclusive income and wealth distribution pattern, which points to the system's inability to reduce poverty.
} 
concentration of property, unfavourable insertion in world trade, elevated concentration of markets, and technological backwardness) and by socio-political factors (e.g.,, frail syndicalist organization, inequality in geographical and sectorial distribution of population, and low educational level) (Missio and Jayme Jr., 2012).

As an analytical exercise, using aspects of ECLAC thought and of the macrostructuralist formalization previously mentioned, a possible interpretation synthesizing the evolution of this thought can be constructed from the structure of a dual model: in the initial phase (1950s and early 1960s), when the centre-periphery view was predominant, the fundamental problem with underdeveloped economies was the presence of structural heterogeneity, represented by the existing dualism between the backward sector (agriculture) and modern sector (industry). In this case, industrialization was recommended as a way to overcome the underdevelopment condition established by centre-periphery dynamics. Later on, some authors, especially Celso Furtado, became 'pessimistic' in relation to the possibility that industrialization alone would be capable of overcoming the backwardness this condition imposed. That is, even with industrialization, underdevelopment could still perpetuate itself.

The neo-structuralist synthesis recovers a great part of this thought, which one can understand by shifting the focus of analysis to sectorial composition ${ }^{13}$. In other words, considering that Latin American economies have already reached a considerable level of industrialization, the key matter is the understanding that structural heterogeneity also manifests itself intra-sectorially. In terms of the previous model, this implies that the dualism is manifested in the industrial sector, for instance, by the presence of a technology-intensive goods producing segment (i.e.,, outputting high aggregate value) in contrast to a low technology segment (i.e.,, one outputting low aggregate value). Indeed, industrialization by itself is not capable of fulfilling the role originally attributed to it, since industrializing becomes a necessary, albeit not sufficient, condition to ensure development. That is, the type of industrialization is essential, especially that which prioritizes the production of technology-intensive goods. Therefore, the condition for overcoming underdevelopment problems goes through the necessity of establishing a new model based on competitiveness and on a better external insertion, especially that centred on the production of the aforementioned segment of products.

\section{CONCLUSIONS}

The structuralist approach is present in several fields of knowledge. In economics, it is strongly associated with the development of ECLAC thought. This ap-

\footnotetext{
${ }^{13}$ This does not imply that neo-structuralist thought has been the only one responsible for observing the relevance in sectorial composition, in part because 'it was in the air', as it may be observed in Furtado's comment (1968, p. 181) about Chenery's study: "There are considered the differences in growth elasticity of the several groups that integrate the industrial sector". This shows that it was up to neo-structuralism to emphasize this point and to propose alternatives to improve this composition. This is a fundamental question, which will be revisited later.
} 
proach admits the existence of specific particularities in developing economies, especially in their institutional and productive structures, constituting bottlenecks that constrain their development. In this case, they undertake a relevant role in the assimilation, development and incorporation of technical progress as a primordial policy in the overcoming of backwardness.

In economic theory, it is possible to identify a genuine Latin American contribution in this approach, from an interpretation that opposes the free functioning of market forces. These contributions result from the substantiation of analyses in the consideration of particular characteristics - which determine and are determined by historical, economic and social transformations (both national and international) - and of the development and application of the historical-structural method. Such an application, upon incorporating historically contingent analyses with non-reductionist, non-mechanistic and non-deterministic dimensions, determines the conception of a world that considers more than just merely economic factors. In effect, it is worth noting its original contribution to the understanding of development and underdevelopment as mutually constituted processes within an economically integrated world, and of the role of the State as an indispensable agent in this process.

From the point of view of the history of economic thought, it is necessary to point out the importance of this approach within theory and within economic policy-making. Its importance can be observed, for instance, in the large success the underdevelopment theory elaborated by ECLAC achieved in Latin America. In Brazil, in particular, this success occurred not only among policy makers but also among industrial entrepreneurs and, over time, within the academy (Colistete, 2001). Nonetheless, its influence decreased throughout the 1970s amidst the neoliberal ascension.

Notwithstanding, the neoliberal negligence of social and political factors in the implementation of its proposals and the resulting frustration in terms of results achieved by it also led to a series of recent questionings that fomented the emergence of new approaches. At ECLAC, these questionings led to the intellectual convergence around the neo-structuralist synthesis.

By emphasizing the presence of sectorial differences, distributive conflict and technological backwardness, among other characteristics of developing countries, the structuralist tradition allows for the understanding of development as a nonharmonious process, from the international to the domestic sphere, as so adequately stated by Hirschman (1958). As Prebish (1962) showed, Latin American countries suffered from a worsening the terms of trade, keeping them in a condition of periphery in the capitalist system, while Furtado (1964) shows how underdevelopment results from an historical process characterized by a distributive conflict. In this sense, the development process generates a series of threads and internal conflicts among the different productive sectors and between social classes. This implies that the income distribution structure can be an important 'blockade' to be overcome upon the adoption of more active policies toward growth.

Therefore, by going beyond the conventional interpretation in the understanding of the processes of growth in underdeveloped economies, this approach constitutes one of the most important theories of development. 


\section{REFERENCES}

ARNDT, H. W. (1975). “The origins of structuralism”. World Development, v. 13, n. 2, 151-159.

BIELSCHOWSKY, R. (1998). Cincuenta años del pensamiento de la CEPAL: una reseña. En Cincuenta años de pensamiento en la CEPAL. Textos seleccionados, vol. 1, Santiago, Chile: Fondo de Cultura Económica.

BIELSCHOWSKY, R. (2000). Pensamento Econômico Brasileiro: O Ciclo Ideológico do Desenvolvimentismo. 4 ed. Rio de Janeiro: Contraponto.

BIELSCHOWSKY, R. (2009). "Sesenta años de la CEPAL: estructuralismo y neoestructuralismo”, Revista CEPAL, n. 97, 173-194.

BLANKENBURG, S.; PALMA, J. G.; TREGENNA, F. (2010). “Structuralism”, The New Palgrave Dictionary of Economics. Second Edition. Edited by. Steven N. Durlauf and Lawrence E. Blume. Palgrave Macmillan, 2008. The New Palgrave Dictionary of Economics Online.

BRESSER-PEREIRA, L. C. (2011). "An account of new developmentalism and its structuralist macroeconomics”. Revista de Economia Política, v. 31, n. 3, 339-351.

BRESSER-PEREIRA, L. C. (2012). "Structuralist macroeconomics and the new developmentalism" Revista de Economia Política, v. 32, n. 3 , 347-366.

BRESSER-PEREIRA, L. C.; GALA, P. (2010). "Macroeconomia estruturalista do desenvolvimento", Revista de Economia Política, v. 30, n. 4, 663-686.

CEPAL. (1990). Transformación Productiva con Equidad. La Tarea Prioritaria del Desarrollo de América Latina y el Caribe en los Años Noventa. Santiago de Chile: CEPAL.

CHENERY, H. (1975). "The structuralist approach to development policy", The American Economic Review, v. LXV, n. 2, 310-316.

COLISTETE, R. (2001). "O desenvolvimentismo cepalino: problemas teóricos e influências no Brasil”, Estudos Avançados, v. 41, n. 15, 21-34.

DI FILIPPO, A. (2009). "Estructuralismo latinoamericamo y teoría económica”, Revista Cepal, n. 98, 181-202.

DUTT, A. K. (1994). “Analytical political economy: an introduction”. New Directions in Analytical Political Economy, ed. A.K. Dutt, Aldershot,. UK: Edward Elgar, 1-30.

DUTT, A.; JAMESON, K. (1992). New Directions in Development Economics, Hants (U.K.): Edward Elgar.

FONSECA, P. C. D. (2009). "A Política e seu lugar no estruturalismo: Celso Furtado e o impacto da grande depressão no Brasil, EconomiA, Selecta, Brasília (DF), v. 10, n. 4, p.867-885, dezembro.

FURTADO, C. (1964). Development and Underdevelopment, Rio de Janeiro, Fundo de Cultura, 1964.

FURTADO, C. (1968). Um Projeto para o Brasil. Rio de Janeiro, Editora Saga.

FURTADO, C. (1974). Teoría y Política del Desarrollo Económico. Cidade do México: Siglo XXI.

FURTADO, C. (1980). Pequena Introdução ao Desenvolvimento: Enfoque Interdisciplinar. Rio de Janeiro, Cia. Editora Nacional.

FURTADO, C. (2000). Teoria e Política do Desenvolvimento Econômico. São Paulo: Paz e Terra (10 ed), [1967].

GAYTÁN, A. K. (1995). "El cambio tecnológico en los análisis estructuralistas”, Revista de La CEPAL, n. $55,183-190$.

GIBSON, B. (2003). “An essay on late structuralism”. In A. Dutt and J. Ros (Eds.), Development Economics and Structuralist Macroeconomics: Essays in Honor of Lance Taylor, Chapter 2, pp. 52-76. Cheltenham, UK: Edward Elgar.

HIRSCHMAN, A. (1958). The Strategy of Economic Development. New Haven, Yale University Press.

JAMESON, K. (1986). "Latin American structuralism: a methodological perspective”, World Development, v. 14, n. 2, 223-232.

JACKSON, W. A. (2003). "Social structure in economic theory", Journal of Economic Issues, v. 37, n. 3, 727-746.

KAY, C.(1989). Latin American Theories of Development and Underdevelopment. London: Routledge.

LEWIS, A. (1954). "Economic development with unlimited supplies of labour", Manchester School of Economic and Social Studies, v. 22, n. 2, 139-191. 
LOVE, J. (1996). "Las fuentes del estructuralismo latinoamericano”, Desarrollo Económico, v. 36, n. $141,391-402$.

LOVE, J. (2005). "The rise and decline of economic structuralism in Latin America: new dimensions", Latin American Research Review, v. 40, n. 3, 100-126.

LUSTIG, N. (1988). "Del estructuralismo al neoestructuralismo: la búsqueda de un paradigma heterodoxo". Cadernos Colección Estudios CIEPLAN, México, n. 25, 35-50.

NURKE, R. (1953). Problems of Capital Formation in Underdeveloped Countries. New York: Oxford University Press.

MALLORQUín, C. (1998). "El estructuralismo de Celso Furtado", Revista Mensual de Política y Cultura n. 117 , noviembre.

MALLORQUÍN, C. (1999). “La historia del estructuralismo de Celso Furtado”, Economia: teoria y prática, n. 10, 55-75.

MISSIO, F. J.; JAYME JR., F. G. (2012). "Estruturalismo e neoestruturalismo: Velhas questões, novos desafios”, Análise Econômica (UFRGS), v. 30, 205-230.

OCAMPO, J. A.; RADA, C.; TAYLOR, L. (2009). Economic Structure, Policy and Growth in Developing Countries. New York: Columbia University Press.

PREBISCH, R. (1962). "El desarrollo económico de América Latina y algunos de sus principales problemas", Boletín Económico América Latina.

RODRIGUEZ, O. (2009). O Estruturalismo Latino-Americano. Rio de Janeiro: Civilização Brasileira.

ROSALES, O (1988). "An assessment of the structuralist paradigm for Latin American development and the prospects of its renovation", Cepal Review, n. 34, 19-36.

ROSENSTEIN-RODAN. (1943). "Problems of industrialization of Eastern and South-Eastern Europe", Economic Journal, vol. 53, 202-211, June-September.

SANCHEZ-ANCOCHEA. (2007). "Anglo-Saxon structuralism vs. Latin American structuralism in development economics". In Ideas, Policies and Economic Development in the Americas edited by E. Perez and M. Varengo, New York: Routledge: 208-227.

SEERS, D. (1962). "A theory of inflation and growth in underdeveloped countries based on the experience of Latin America", Oxford Economic Papers, 14, 173-95.

SUNKEL, O.; Paz, P. (1970). Subdesarrollo Latinoamericano y La Teoria Del Desarrollo, Mexico City, Siglo Veintiuno.

SUNKEL, O.; Paz, P. (1989). "Structuralism, dependency and institutionalism: An exploration of common ground and disparities", Journal of Economic Issues, v. 23, n. 2, 519-533.

STREET, J. H. (1967). "The Latin American "structuralists" and the institutionalists: Convergence in development theory", Journal of Economic Issues, v. 1, n. 1-2, 44-62.

STREET, J. H.; JAMES, D. D. (1982). "Institutionalism, structuralism, and dependency in Latin America", Journal of Economic Issues, v. 16, n. 3, 673-689.

TAYLOR, L. (1979). Macro Models for Developing Countries. New York: McGraw-Hill.

TAYLOR, L. (1983). Structuralist Macroeconomics, New York: Basic Books.

TAYLOR, L. (1991). Growth, Income Distribution and Inflation: Lectures on Structuralist Macroeconomic Theory, Cambridge, Massachusetts: MIT Press. 